\title{
Ammonia Movement in the Small Intestine: Preferential Transport by the Ileum*
}

\author{
Sanford M. Mossberg † And George Ross \\ (From the Department of Gastroenterology, Medical Division, and Laboratory Division, \\ Montefiore Hospital and Medical Center, New York. N. Y.)
}

\begin{abstract}
Summary. Isolated, surviving sacs of everted small intestine were used to characterize ammonia transport in the golden hamster. Jejunal and ileal sacs incubated aerobically in ammonia-free test solution liberated the same quantity of ammonia as did sacs that were filled and immediately emptied of their contents, indicating no significant evolution of metabolic ammonia.

Under aerobic conditions, ileal sacs transferred a solution of high ammonia content from the mucosal surface to the serosal surface against a concentration gradient. This transport was not glucose dependent and exhibited first-order Michaelis-Menten kinetics. Inhibition of absorption occurred with anaerobiosis, 2,4-dinitrophenol, and sodium cyanide. In jejunal segments ammonia was not transported against an adverse chemical gradient. Ileal ammonia absorption was accompanied by bicarbonate secretion and acidification of the serosal solution. Both bicarbonate movement and $\mathrm{pH}$ gradients were abolished by inhibitors of ammonia transport. In the jejunum, the absence of ammonia movement occurred in association with minimal bicarbonate secretion and no appreciable change in serosal $\mathrm{pH}$.

Despite the creation of hydrogen ion gradients tending to augment or to retard ammonia absorption by nonionic diffusion, ammonia movement was unaffected, i.e., relative acidification of serosal contents did not augment ammonia absorption, and relative alkalinization of serosal fluid caused no inhibition of ammonia transport. In the absence of bicarbonate ion, ammonia transport did not occur. The significance of these findings is discussed with consideration of both ionic and nonionic mechanisms of ammonia movement. It is suggested that ammonia is absorbed in the ileum by active ionic transport.
\end{abstract}

\section{Introduction}

Although ammonia is formed endogenously by the kidney $(1,2)$ and other organs $(3,4)$, the major component of blood ammonia originates in the colon and small intestine from the decomposition of protein, amino acids, and urea (5-7). In the normal animal, portal vein ammonia enters

* Submitted for publication May 4, 1966; accepted December 8, 1966.

Supported by U. S. Public Health Service grant AM-07905 from the National Institute of Arthritis and Metabolic Diseases.

$\dagger$ Address requests for reprints to Dr. Sanford M. Mossberg, 33 Quaker Ridge Rd., New Rochelle, N. Y. the liver and is converted into urea. When the hepatic parenchyma is damaged or when portosystemic vascular shunts are present, excess ammonia passes into the general circulation and is thought to produce hepatic coma (8-10). A regimen designed to reduce ammonia formation in the alimentary canal has been the mainstay of treatment for this toxic neurologic syndrome $(11,12)$; however, despite rigorous protein restriction, purgation, and bowel sterilization, hepatic coma is often irreversible.

Additional therapeutic benefit might be derived from a knowledge of the factors regulating ammonia absorption. It was the purpose of this 
study, therefore, to investigate the characteristics of ammonia transport by the small intestine in vitro.

In the following presentation, "ammonia" is used as a generic term to refer to the $\mathrm{NH}_{4}{ }^{+}-\mathrm{NH}_{3}$ system. "Ammonium" indicates $\mathrm{NH}_{4}{ }^{+}$, and "free ammonia" (ammonia gas, $\mathrm{PNH}_{3}$ ) refers to $\mathrm{NH}_{3}$.

\section{Methods}

Adult golden hamsters were fasted for 24 hours and killed by a sharp blow on the head. The abdomen was opened, and, after transection of the small intestine at the proximal jejunum and terminal ileum, the isolated gut was stripped manually from the mesentery and flushed with test solution. Careful cleansing of the serosal surface was followed by eversion of the intestine on a $2-\times 300-\mathrm{mm}$ steel $\mathrm{rod}(13)$. Washing of the mucosal and serosal surfaces was repeated so that ammonia-containing blood and debris were removed but the intestine was not injured. With the gut immersed in test solution, 5- to $10-\mathrm{cm}$ segments of jejunum and ileum were cut and tied at one end with 4-0 silk ligature. A blunt needle attached to a calibrated syringe was inserted into the open end of the intestine, each sac was filled with an amount of liquid ( 0.15 to $0.25 \mathrm{ml}$ per $\mathrm{cm}$ ) that would cause neither overdistention nor underfilling, and the open end of the sac was tied. After being weighed, the sacs were placed in 125-ml Erlenmeyer flasks containing $50 \mathrm{ml}$ of test solution, and the stoppered flasks were set into a Dubnoff metabolic shaking incubator at $37^{\circ} \mathrm{C}$ and $60 \mathrm{rpm}$ for 60 minutes in an atmosphere of $95 \% \mathrm{O}_{2}-5 \% \mathrm{CO}_{2}, 95 \% \mathrm{~N}_{2}-5 \% \mathrm{CO}_{2}$, or $100 \%$ $\mathrm{O}_{2}$. At the conclusion of the incubation period, the sacs were blotted, reweighed, and emptied. The final mucosal volume was inferred from the alteration in serosal volume. The dry weight of the empty sac was obtained after desiccation in an oven for 2 hours at $110^{\circ} \mathrm{C}$.

Solutions were prepared with water rendered ammonium-free by passage through a sulfonic acid exchange resin. ${ }^{1}$ Test solutions contained Krebs-Ringerbicarbonate (KRB) or Krebs-Ringer-phosphate (KRP) (14) to which either glucose $16.5 \mathrm{mM}$ or ammonia nitrogen $\left(\mathrm{NH}_{3}-\mathrm{N}\right) 6.14$ to $90.00 \mathrm{mM}$ as ammonium chloride, or both, were added. Either hydrochloric acid $1.0 \mathrm{~N}$ or sodium hydroxide $1.0 \mathrm{~N}$ was used to alter the $\mathrm{pH}$ of the test solution. Each of the final mucosal and serosal specimens was passed through medium porosity (10 to $15 \mu$ ) and fine porosity ( 4 to $5.5 \mu$ ) filters to remove nitrogenous particulate matter. Neither exposure to air nor filtration caused a measurable change in $\mathrm{NH}_{3}-\mathrm{N}$ at a $\mathrm{pH}$ below 8.0. In experiments requiring total $\mathrm{CO}_{2}$ and $\mathrm{pH}$ measurements, unfiltered specimens were collected and immediately layered with mineral oil so that loss of gaseous $\mathrm{CO}_{2}$ into the atmosphere was minimized.

Chemical determinations were performed in duplicate

1 IR 120, Rohm \& Haas, Philadelphia, $\mathrm{Pa}$.
TABLE I

Liberation of ammonia by everted intestinal sacs bathed in ammonia-free solution*

\begin{tabular}{|c|c|c|c|}
\hline $\begin{array}{l}\text { Increase in } \\
\text { serosal } \mathrm{NH}_{3}-\mathrm{N}\end{array}$ & Incubated $\dagger$ & Unincubated $\ddagger$ & $\mathbf{p}$ \\
\hline \multicolumn{4}{|c|}{ Ileum } \\
\hline Concentration & $0.228 \pm 0.034 \S(12) \|$ & $0.206 \pm 0.025$ & $>0.8$ \\
\hline Total ( $\mu$ mole) & $0.414 \pm 0.060$ & $0.400 \pm 0.048$ & $>0.6$ \\
\hline \multicolumn{4}{|c|}{ Jejunum } \\
\hline $\begin{array}{c}\text { Concentration } \\
(\text { mmole } / \mathrm{L})\end{array}$ & $0.275 \pm 0.074$ & $0.246 \pm 0.037(10)$ & $>0.2$ \\
\hline Total ( $\mu$ mole) & $0.453 \pm 0.088$ & $0.334 \pm 0.050$ & $>0.6$ \\
\hline
\end{tabular}

* Krebs-Ringer-bicarbonate-glucose on mucosal and serosal sides.

+ At $37^{\circ} \mathrm{C}$ for 60 minutes under $95 \% \mathrm{O}_{2}-5 \% \mathrm{CO}_{2}$.

$\ddagger$ Filled and immediately emptied.

Mean value plus or minus standard error of the mean.

Number of sacs in parentheses.

from samples of initial and final serosal and mucosal fluid. $\mathrm{NH}_{3}-\mathrm{N}$ was measured by the method of Seligson and Hirahara (15), glucose by the method of Nelson (16), and total $\mathrm{CO}_{2}$ by the Technicon Autoanalyzer. $\mathrm{pH}$ determinations were performed at $37^{\circ} \mathrm{C}$ with a Sargent combined glass and calomel electrode and a Beckman model $\mathrm{G}$ pH meter.

A relatively large volume $(50 \mathrm{ml})$ of outer solution was used so that a fluid of nearly constant composition was presented to the mucosa. Because of its small size $(0.8$ to $2.0 \mathrm{ml})$, the serosal compartment reflected minute changes in fluid composition. Thus, the gain or loss of a substance from the serosal fluid was taken to indicate net positive transport (absorption) or negative transport (secretion), respectively. Two parameters of ammonia transport were measured: 1) total micromoles of $\mathrm{NH}_{3}-\mathrm{N}$ transferred from the mucosal to the serosal surface per $1 \mathrm{mg}$ dry sac weight per hour, and 2) percentage increase in serosal $\mathrm{NH}_{3}-\mathrm{N}$ concentration per hour. Significance between groups was calculated by Student's $t$ test.

\section{Results}

Liberation of ammonia by the experimental model. Ileal and jejunal sacs incubated aerobically in ammonia-free KRB-glucose for $60 \mathrm{~min}$ utes at $37^{\circ} \mathrm{C}$ liberated small amounts of $\mathrm{NH}_{3}-\mathrm{N}$ into the serosal fluid. When corresponding sacs were filled and immediately emptied of their contents, similar quantities of serosal $\mathrm{NH}_{3}-\mathrm{N}$ appeared (Table I). Since the amounts of $\mathrm{NH}_{3}-\mathrm{N}$ liberated both by incubated and unincubated sacs were not significantly different, the origin of the ammonia was presumed to be extrinsic, rather than metabolic. In subsequent experiments no correction was made for this small quantity of ammonia, because it comprised less than $5 \%$ of the total serosal $\mathrm{NH}_{3}-\mathrm{N}$. 
TABLE II

Aerobic transport of ammonia*

\begin{tabular}{|c|c|c|c|c|}
\hline $\mathrm{NH}_{2}-\mathrm{N}$ transport & Test solution & Ileum & Jejunum & $\mathrm{p}$ \\
\hline \multirow{2}{*}{$\begin{array}{l}\text { Total, } \Delta \mu \text { moles serosal } \\
\mathrm{NH}_{3}-\mathrm{N} / \mathrm{mg} \text { dry wt/ } \\
60 \mathrm{~min}\end{array}$} & KRB-glucose $-\mathrm{NH}_{3}-\mathrm{N}$ & $0.315 \pm 0.034 \nmid(18) \ddagger$ & $0.065 \pm 0.012(18)$ & $<0.001$ \\
\hline & $\mathrm{KRB}-\mathrm{NH}_{3}-\mathrm{N}$ & $0.159 \pm 0.031(8)$ & $0.027 \pm 0.018$ & $<0.01$ \\
\hline $\begin{array}{l}\text { Percentage, } \% \Delta \text { mmoles } / L \\
\text { serosal } \mathrm{NH}_{3}-\mathrm{N} / 60 \mathrm{~min}\end{array}$ & $\begin{array}{l}\text { KRB-glucose- } \mathrm{NH}_{3}-\mathrm{N} \\
\mathrm{KRB}-\mathrm{NH}_{3}-\mathrm{N}\end{array}$ & $\begin{array}{l}38.3 \pm 3.70 \\
34.8 \pm 6.08\end{array}$ & $\begin{array}{l}0.46 \pm 2.58 \\
2.10 \pm 3.54\end{array}$ & $\begin{array}{l}<0.001 \\
<0.001\end{array}$ \\
\hline $\begin{array}{l}\text { Solution transported, } \Delta \\
\mu \text { moles serosal } \mathrm{NH}_{3}-\mathrm{N} / \Delta \\
\text { ml serosal fluid } / 60 \mathrm{~min}\end{array}$ & KRB-glucose- $\mathrm{NH}_{3}-\mathrm{N} \S$ & $33.9 \pm 3.87$ & $9.59 \pm 1.28$ & $<0.001$ \\
\hline
\end{tabular}

* Sacs incubated for 60 minutes at $37^{\circ} \mathrm{C}$ in test solution containing 6.14 to $14.85 \mathrm{mM} \mathrm{NH}-\mathrm{N}$ and gassed with $95 \%$ $\mathrm{O}_{2}-5 \% \mathrm{CO}_{2}$. $\mathrm{KRB}=$ Krebs-Ringer-bicarbonate.

$\dagger$ Mean value plus or minus standard error of the mean.

Number of sacs in parentheses.

$\S$ Average $\mathrm{NH}_{3}-\mathrm{N}$ concentration of initial test solution $:$ ileum $=11.04$ mmoles per $\mathrm{L}$, jejunum $=11.08 \mathrm{mmoles}$ per $\mathrm{L}$.

Ammonia transport under aerobic conditions. Sacs of ileum and jejunum were incubated for 60 minutes at $37^{\circ} \mathrm{C}$ in $\mathrm{KRB}$-glucose containing 6.14 to $14.85 \mathrm{mM} \mathrm{NH}_{3}-\mathrm{N}$ and gassed with $95 \% \mathrm{O}_{2}-5 \%$ $\mathrm{CO}_{2}$. Movement of ammonia from the mucosal to

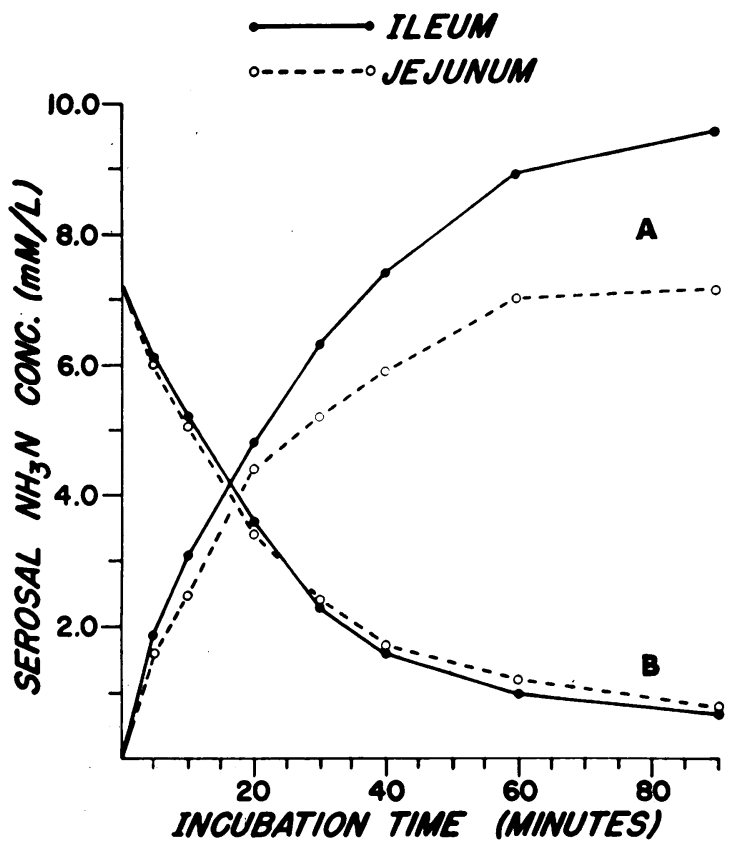

Fig. 1. Comparison of UNIDIRECTIONAL NET MOVEMENT OF AMMONIA IN THE ILEUM AND JEJUNUM AS MEASURED BY CHANGE IN SEROSAL $\mathrm{NH}_{3}-\mathrm{N}$ CONCENTRATION AFTER AEROBIC inCUbation at $37^{\circ} \mathrm{C}$ with KREBSRinger-BICARBonate CONTAINING $7.1 \mathrm{MM} \mathrm{NH}_{3}-\mathrm{N}$ INITIALLY ON THE MUCOSAL SIDE (A) OR ON THE SEROSAL SIDE (B). Mucosal volume is $50 \mathrm{ml}$ and serosal volume is 1 to $2 \mathrm{ml}$. Each point represents the mean value from 4 sacs. the serosal compartment occurred in the ileum to a significantly greater extent than in the jejunum. When the concentration of the solution transported was calculated by dividing the total micromoles of $\mathrm{NH}_{3}-\mathrm{N}$ transported by the milliliters of fluid moved during the 1-hour incubation, the ileum was found to transfer a solution of higher $\mathrm{NH}_{3}-\mathrm{N}$ concentration than the initial test solution, whereas the fluid crossing the jejunal mucosa was not changed significantly. Results are summarized in Table II. No difference was noted in the ability of either intestinal segment to transfer glucose and water from the mucosal to serosal surface (not shown).

To test whether the transport of ammonia was glucose dependent, we incubated the sacs aerobically for 60 minutes at $37^{\circ} \mathrm{C}$ in glucose-free $\mathrm{KRB}$ containing 13.16 to $14.37 \mathrm{mM} \mathrm{NH}_{3}-\mathrm{N}$. Under these conditions, electrolyte movement took place, but fluid exchange was minimal, a slight water loss occurring in the ileum $(-7.6 \% \pm \mathrm{SE}$ $1.73 \%$ ) and a small serosal water gain resulting in the jejunum $(7.7 \% \pm \mathrm{SE} 3.36 \%)$. In jejunal sacs, neither parameter of ammonia transport was altered by the absence of glucose. In ileal segments, the percentage increase in serosal $\mathrm{NH}_{3}-\mathrm{N}$ was similar to that in sacs incubated with glucose, but the total serosal ammonia gain was decreased because of the limited fluid movement. It was apparent, therefore, that glucose is not essential for the passage of $\mathrm{NH}_{3}-\mathrm{N}$ from the mucosal to the serosal surface against a chemical gradient. Results are listed in Table II.

To determine whether a selective permeability 
to ammonia existed in either the ileum or the jejunum, we incubated the sacs for periods of time varying from 5 to 90 minutes with $\mathrm{KRB}$ containing $7.1 \mathrm{mM} \mathrm{NH}_{3}-\mathrm{N}$ initially on only one side of the gut wall. As recorded in Figure 1, the serosal to mucosal movement of ammonia did not differ in the jejunum and ileum, whereas the mucosal to serosal passage of $\mathrm{NH}_{3}-\mathrm{N}$ was larger in the ileum. Thus, a greater net transport of $\mathrm{NH}_{3}-\mathrm{N}$ in the ileum appeared to be related not to a difference in flux out of the serosal compartment, but, rather, to a greater ileal movement of ammonia from the mucosal side into the serosal compartment.

When ileal sacs were incubated in test solutions containing progressively larger initial concentrations of ammonia (6.14 to $90.00 \mathrm{mM} \mathrm{NH}_{3}-\mathrm{N}$ ) and the results analyzed by a Lineweaver-Burk plot (17), a straight line relationship was obtained (Figure 2), suggesting either an enzymedependent or a surface-catalyzed reaction.

Effect of anaerobiosis and metabolic inhibitors on ammonia transport. In ileal segments incubated for 60 minutes at $37^{\circ} \mathrm{C}$ in KRB-glucose gassed with $95 \% \mathrm{~N}_{2}-5 \% \mathrm{CO}_{2}$, there was no net movement of ammonia. The final serosal/mucosal concentration ratio, although reduced sig-

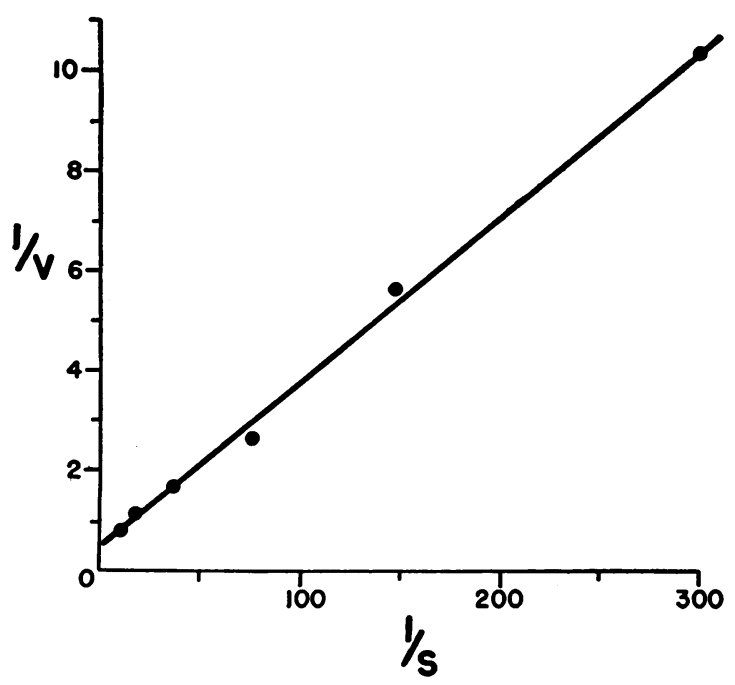

Fig. 2. Lineweaver-Burk plot of Ileal ammonia TRANSPORT. Sacs incubated aerobically at $37^{\circ} \mathrm{C}$ for 1 hour with Krebs-Ringer-bicarbonate-glucose containing 6.14 to $90.00 \mathrm{mM} \mathrm{NH}-\mathrm{N}$. Reciprocal of initial $\mathrm{NH}_{3}-\mathrm{N}$ concentration used for $1 / \mathrm{S}$; reciprocal of ammonia transference quotient (micromoles of $\mathrm{NH}_{3}-\mathrm{N}$ transported per milligram dry weight per hour) used for $1 / \mathrm{V}$. Each point represents the average value from 4 to 14 sacs.

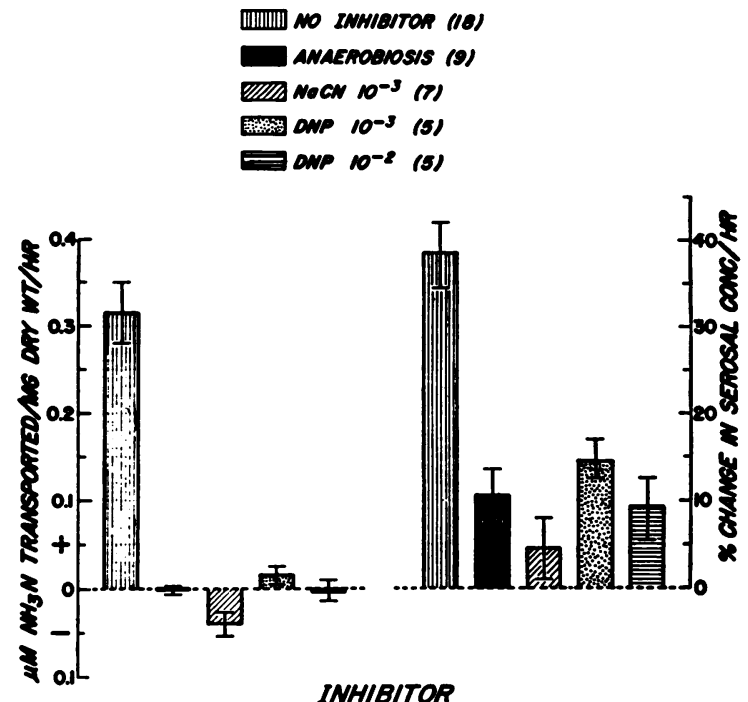

Fig. 3. EFFect of ANAERobiosis, SOdium CYANIDE, AND 2,4-DINITROPHENOL (DNP) ON AMMONIA TRANSPORT IN THE ILEUM. Two parameters of transport are depicted. The number of sacs tested with each inhibitor is listed in parentheses. The height of the bar represents the mean value, and the parallel lines indicate the standard error above and below the mean.

nificantly $(p<0.001)$ in comparison to sacs incubated aerobically, remained greater than one, indicating serosal water loss in excess of serosal $\mathrm{NH}_{3}-\mathrm{N}$ loss, i.e., movement of a fluid of low or absent $\mathrm{NH}_{3}-\mathrm{N}$ content from the serosal to the mucosal surface. Incubation with $\mathrm{NaCN} 10^{-3} \mathrm{M}$ and 2,4-dinitrophenol $10^{-3} \mathrm{M}$ and $10^{-2} \mathrm{M}$ also reduced or abolished net ammonia transport in the ileum, despite the maintenance of a slightly positive serosal concentration gradient. Results are depicted in Figure 3.

Ammonia transport was completely inhibited in jejunal sacs incubated either anaerobically, with $\mathrm{NaCN}$, or with dinitrophenol. As in aerobic experiments, the serosal $\mathrm{NH}_{3}-\mathrm{N}$ concentration in the jejunum did not change appreciably.

Acid-base changes and ammonia movement. After aerobic incubation for 60 minutes at $37^{\circ} \mathrm{C}$ in sugar-free KRB, small intestinal segments developed concentration gradients of ammonia, $\mathrm{CO}_{2}$, chloride, and hydrogen ions across their walls. In the absence of glucose, neither lactic acid formation nor fluid transport occurred to an appreciable extent, thus reducing the complicating effects of these two processes on acid-base changes. Because of the relatively large volume of mucosal 
TABLE III

Aerobic and anaerobic movement of ammonia, total $\mathrm{CO}_{2}$, and hydrogen ion in glucose-free test solution*

\begin{tabular}{|c|c|c|c|c|c|c|c|c|c|c|c|c|}
\hline \multirow[b]{3}{*}{ Sac } & \multirow{3}{*}{$\begin{array}{c}\text { Gut } \\
\text { segment }\end{array}$} & \multicolumn{9}{|c|}{ Serosal compartment } & \multirow{2}{*}{\multicolumn{2}{|c|}{$\underset{\text { partment }}{\text { Mucosal com- }}$}} \\
\hline & & \multicolumn{2}{|c|}{ Volume } & \multicolumn{2}{|c|}{$\mathrm{NH}_{3}-\mathrm{N}$} & \multicolumn{2}{|c|}{ Total $\mathrm{CO}_{2}$} & \multicolumn{2}{|c|}{$\mathrm{pH}$} & \multirow{2}{*}{$\frac{\mathrm{PNH}_{3}}{\text { Final }}$} & & \\
\hline & & Initial & Final & Initial & Final & Initial & Final & Initial & Final & & $\mathrm{pH}$ & $\mathrm{PNH}_{3}$ \\
\hline & & \multicolumn{2}{|c|}{$m l$} & \multicolumn{2}{|c|}{ umoles } & \multicolumn{2}{|c|}{$\mu$ moles } & & & \multicolumn{2}{|l|}{$\begin{array}{l}10^{-2} \\
m m \mathrm{Hg}\end{array}$} & $\begin{array}{l}10^{-2} \\
m m ~ H g\end{array}$ \\
\hline & \multicolumn{9}{|c|}{ Aerobic incubation $\ddagger$} & & & \\
\hline $\begin{array}{l}10434 \\
10456\end{array}$ & I & $\begin{array}{l}1.50 \\
1.40\end{array}$ & $\begin{array}{l}1.50 \\
1.42\end{array}$ & $\begin{array}{l}21.0 \\
19.6\end{array}$ & $\begin{array}{l}26.7 \\
19.6\end{array}$ & $\begin{array}{l}32.7 \\
30.5\end{array}$ & $\begin{array}{l}25.2 \\
28.8\end{array}$ & $\begin{array}{l}7.48 \\
7.48\end{array}$ & $\begin{array}{l}7.26 \\
7.46\end{array}$ & $\begin{array}{l}0.78 \\
0.96\end{array}$ & $\begin{array}{l}7.48 \\
7.48\end{array}$ & $\begin{array}{l}1.02 \\
1.01\end{array}$ \\
\hline $\begin{array}{l}10356 \\
10334\end{array}$ & I & $\begin{array}{l}1.70 \\
2.00\end{array}$ & $\begin{array}{l}1.64 \\
2.06\end{array}$ & $\begin{array}{l}23.3 \\
27.4\end{array}$ & $\begin{array}{l}30.5 \\
27.6\end{array}$ & $\begin{array}{l}36.7 \\
43.2\end{array}$ & $\begin{array}{l}25.9 \\
42.4\end{array}$ & $\begin{array}{l}7.51 \\
7.51\end{array}$ & $\begin{array}{l}7.28 \\
7.53\end{array}$ & $\begin{array}{l}0.84 \\
1.09\end{array}$ & $\begin{array}{l}7.51 \\
7.51\end{array}$ & $\begin{array}{l}1.07 \\
1.07\end{array}$ \\
\hline $\begin{array}{l}103910 \\
10378\end{array}$ & $\begin{array}{l}\text { I } \\
\text { J }\end{array}$ & $\begin{array}{l}1.70 \\
2.00\end{array}$ & $\begin{array}{l}1.63 \\
2.10\end{array}$ & $\begin{array}{l}23.3 \\
27.4\end{array}$ & $\begin{array}{l}27.5 \\
28.8\end{array}$ & $\begin{array}{l}36.7 \\
43.2\end{array}$ & $\begin{array}{l}28.4 \\
43.7\end{array}$ & $\begin{array}{l}7.61 \\
7.61\end{array}$ & $\begin{array}{l}7.38 \\
7.60\end{array}$ & $\begin{array}{l}0.98 \\
1.31\end{array}$ & $\begin{array}{l}7.61 \\
7.61\end{array}$ & $\begin{array}{l}1.35 \\
1.35\end{array}$ \\
\hline $\begin{array}{l}10234 \\
10256\end{array}$ & I & $\begin{array}{l}1.80 \\
1.90\end{array}$ & $\begin{array}{l}1.78 \\
1.90\end{array}$ & $\begin{array}{l}24.7 \\
26.0\end{array}$ & $\begin{array}{l}34.9 \\
24.3\end{array}$ & $\begin{array}{l}39.1 \\
41.2\end{array}$ & $\begin{array}{l}29.4 \\
41.1\end{array}$ & $\begin{array}{l}7.26 \\
7.26\end{array}$ & $\begin{array}{l}7.01 \\
7.26\end{array}$ & $\begin{array}{l}0.48 \\
0.56\end{array}$ & $\begin{array}{l}7.26 \\
7.26\end{array}$ & $\begin{array}{l}0.60 \\
0.60\end{array}$ \\
\hline $\begin{array}{l}10278 \\
102910\end{array}$ & I & $\begin{array}{l}1.50 \\
1.80\end{array}$ & $\begin{array}{l}1.51 \\
1.89\end{array}$ & $\begin{array}{l}20.7 \\
24.7\end{array}$ & $\begin{array}{l}24.8 \\
27.2\end{array}$ & $\begin{array}{l}32.6 \\
39.1\end{array}$ & $\begin{array}{l}24.9 \\
39.1\end{array}$ & $\begin{array}{l}7.33 \\
7.33\end{array}$ & $\begin{array}{l}7.18 \\
7.30\end{array}$ & $\begin{array}{l}0.60 \\
0.69\end{array}$ & $\begin{array}{l}7.33 \\
7.33\end{array}$ & $\begin{array}{l}0.71 \\
0.70\end{array}$ \\
\hline $\begin{array}{l}10534 \\
10556\end{array}$ & I & $\begin{array}{l}1.80 \\
1.70\end{array}$ & $\begin{array}{l}1.80 \\
1.70\end{array}$ & $\begin{array}{l}25.7 \\
24.3\end{array}$ & $\begin{array}{l}33.5 \\
21.7\end{array}$ & $\begin{array}{l}38.7 \\
36.6\end{array}$ & $\begin{array}{l}26.3 \\
35.2\end{array}$ & $\begin{array}{l}7.55 \\
7.55\end{array}$ & $\begin{array}{l}7.29 \\
7.57\end{array}$ & $\begin{array}{l}0.88 \\
1.15\end{array}$ & $\begin{array}{l}7.55 \\
7.55\end{array}$ & $\begin{array}{l}1.22 \\
1.20\end{array}$ \\
\hline \multicolumn{13}{|c|}{ Anaerobic incubation§ } \\
\hline $\begin{array}{l}10734 \\
10756\end{array}$ & I & $\begin{array}{l}1.90 \\
2.00\end{array}$ & $\begin{array}{l}1.69 \\
1.83\end{array}$ & $\begin{array}{l}24.8 \\
26.0\end{array}$ & $\begin{array}{l}22.5 \\
22.9\end{array}$ & $\begin{array}{l}42.7 \\
45.0\end{array}$ & $\begin{array}{l}35.0 \\
39.7\end{array}$ & $\begin{array}{l}7.60 \\
7.60\end{array}$ & $\begin{array}{l}7.65 \\
7.62\end{array}$ & & & \\
\hline $\begin{array}{l}10778 \\
107910\end{array}$ & I & $\begin{array}{l}1.30 \\
1.80\end{array}$ & $\begin{array}{l}1.18 \\
1.55\end{array}$ & $\begin{array}{l}16.9 \\
23.4\end{array}$ & $\begin{array}{l}16.9 \\
21.5\end{array}$ & $\begin{array}{l}29.3 \\
40.5\end{array}$ & $\begin{array}{l}24.3 \\
33.5\end{array}$ & $\begin{array}{l}7.63 \\
7.63\end{array}$ & $\begin{array}{l}7.65 \\
7.67\end{array}$ & & & \\
\hline $\begin{array}{l}10834 \\
10856\end{array}$ & $\begin{array}{l}\text { I } \\
\text { J }\end{array}$ & $\begin{array}{l}1.90 \\
1.80\end{array}$ & $\begin{array}{l}1.71 \\
1.71\end{array}$ & $\begin{array}{l}23.6 \\
22.3\end{array}$ & $\begin{array}{l}21.7 \\
21.9\end{array}$ & $\begin{array}{l}41.8 \\
39.6\end{array}$ & $\begin{array}{l}35.7 \\
36.4\end{array}$ & $\begin{array}{l}7.65 \\
7.65\end{array}$ & $\begin{array}{l}7.67 \\
7.67\end{array}$ & & & \\
\hline $\begin{array}{l}10878 \\
108910\end{array}$ & $\begin{array}{l}\mathrm{I} \\
\mathrm{J}\end{array}$ & $\begin{array}{l}1.90 \\
1.40\end{array}$ & $\begin{array}{l}1.65 \\
1.29\end{array}$ & $\begin{array}{l}23.6 \\
17.4\end{array}$ & $\begin{array}{l}20.9 \\
16.2\end{array}$ & $\begin{array}{l}41.8 \\
30.8\end{array}$ & $\begin{array}{l}35.0 \\
27.1\end{array}$ & $\begin{array}{l}7.67 \\
7.67\end{array}$ & $\begin{array}{l}7.67 \\
7.70\end{array}$ & & & \\
\hline
\end{tabular}

* Paired ileal (I) and jejunal $(\mathrm{J})$ sacs incubated in glucose-free $\mathrm{KRB}$ at $37^{\circ} \mathrm{C}$ for 60 minutes. $\mathrm{PNH}_{3}=\mathrm{partial}$ pressure of ammonia.

$\dagger$ No significant change in $\mathrm{pH}$ or solute concentration occurred on the mucosal side after incubation. Initial mucosal volume $=50 \mathrm{ml}$.

Atmosphere of $95 \% \mathrm{O}_{2}-5 \% \mathrm{CO}_{2}$.

$\S$ Atmosphere of $95 \% \mathrm{~N}_{2}-5 \% \mathrm{CO}_{2}$.

solution $(50 \mathrm{ml})$ in comparison to the fluid in the serosal compartment ( $2 \mathrm{ml}$ or less), initial and final mucosal $\mathrm{pH}$ and electrolyte concentrations did not differ significantly. In the ileum, a net serosal gain of ammonia occurred in association with a decrease in serosal $\mathrm{pH}$ and a loss of serosal total $\mathrm{CO}_{2}$. In jejunal sacs, there was no significant change in either serosal ammonia or $\mathrm{pH}$ after incubation, and a slight reduction in serosal total $\mathrm{CO}_{2}$ was observed. Under anaerobic conditions, inhibition of ileal ammonia transport took place in conjunction with the abolition of $\mathrm{pH}$ and $\mathrm{CO}_{2}$ gradients. These findings are outlined in Table III.

Free ammonia exerts a partial pressure that can be calculated by the following equation (18) :

$$
\mathrm{PNH}_{3}=\left(\frac{\mathrm{TNH}_{3}}{\left[\mathrm{aH}^{+}\right] / \mathrm{K}^{\prime} \mathrm{a}}+1\right) \frac{22.09}{\alpha},
$$

where $\mathrm{PNH}_{3}$ is the partial pressure of ammonia (millimeters $\mathrm{Hg}$ ), $\mathrm{TNH}_{3}$ is total ammonia (moles per liter), $\left[\mathrm{aH}^{+}\right]$is the hydrogen ion activity as measured by the glass electrode (moles per liter), $\mathrm{K}^{\prime} \mathrm{a}$ is the equilibrium constant for plasma taken as $9.8 \times 10^{-10}$ at $37^{\circ} \mathrm{C}$, and $\alpha$ is the solubility coefficient of ammonia in plasma taken as 0.9 . The above equation then simplifies to:

$$
\mathrm{PNH}_{3}=\frac{\mathrm{TNH}_{3}}{\left[\mathrm{aH}^{+}\right]}\left(2.41 \times 10^{-8}\right) .
$$


TABLE IV

Relation of $p H$ and $\mathrm{PNH}_{3}$ gradients to ammonia transpcrt in the ileum*

\begin{tabular}{|c|c|c|c|c|c|c|c|c|}
\hline \multirow[b]{3}{*}{ Sac } & \multicolumn{6}{|c|}{ Serosal compartment } & \multicolumn{2}{|c|}{ Mucosal compartment $\dagger$} \\
\hline & \multicolumn{2}{|c|}{ Volume } & \multicolumn{2}{|c|}{$\mathrm{NH}_{3}-\mathrm{N}$} & \multirow{2}{*}{$\frac{\mathrm{pH}}{\text { Fina! }}$} & \multirow{2}{*}{$\frac{\mathrm{PNH}_{3}}{\text { Final }}$} & \multirow{2}{*}{$\frac{\mathrm{pH}}{\text { Final }}$} & \multirow{2}{*}{$\frac{P_{\text {NH } 3}}{\text { Final }}$} \\
\hline & Initial & Final & Initial & Final & & & & \\
\hline & \multicolumn{2}{|c|}{$m l$} & \multicolumn{3}{|c|}{ 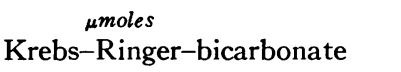 } & $10^{-2} \mathrm{~mm} \mathrm{Hg}$ & & $10^{-2} \mathrm{~mm} \mathrm{Hg}$ \\
\hline $\begin{array}{l}12134 \\
12178 \\
13434\end{array}$ & $\begin{array}{l}1.70 \\
2.00 \\
1.40\end{array}$ & $\begin{array}{l}1.61 \\
2.06 \\
1.38\end{array}$ & $\begin{array}{l}23.5 \\
27.6 \\
19.6\end{array}$ & $\begin{array}{l}27.7 \\
39.6 \\
25.0\end{array}$ & $\begin{array}{l}7.72 \\
7.73 \\
7.74\end{array}$ & $\begin{array}{l}2.18 \\
2.49 \\
2.40\end{array}$ & $\begin{array}{l}7.10 \\
7.11 \\
7.19\end{array}$ & $\begin{array}{l}0.42 \\
0.43 \\
0.52\end{array}$ \\
\hline $\begin{array}{l}11934 \\
12034 \\
12078\end{array}$ & $\begin{array}{l}1.70 \\
2.00 \\
1.80\end{array}$ & $\begin{array}{l}1.61 \\
1.92 \\
1.71\end{array}$ & $\begin{array}{l}25.3 \\
29.6 \\
26.6\end{array}$ & $\begin{array}{l}30.6 \\
35.6 \\
28.7\end{array}$ & $\begin{array}{l}6.89 \\
7.01 \\
7.00\end{array}$ & $\begin{array}{l}0.35 \\
0.45 \\
0.40\end{array}$ & $\begin{array}{l}7.45 \\
7.87 \\
7.87\end{array}$ & $\begin{array}{l}1.01 \\
2.65 \\
2.65\end{array}$ \\
\hline \multicolumn{9}{|c|}{ Krebs-Ringer-phosphate } \\
\hline $\begin{array}{l}12734 \\
12878 \\
13534\end{array}$ & $\begin{array}{l}1.70 \\
2.00 \\
1.20\end{array}$ & $\begin{array}{l}1.60 \\
1.91 \\
1.16\end{array}$ & $\begin{array}{l}22.6 \\
28.0 \\
16.3\end{array}$ & $\begin{array}{l}20.2 \\
25.0 \\
15.0\end{array}$ & $\begin{array}{l}7.10 \\
7.42 \\
7.27\end{array}$ & $\begin{array}{l}0.38 \\
0.83 \\
0.58\end{array}$ & $\begin{array}{l}7.28 \\
7.63 \\
7.41\end{array}$ & $\begin{array}{l}0.61 \\
1.44 \\
0.84\end{array}$ \\
\hline \multicolumn{9}{|c|}{ Krebs-Ringer-phosphate-glucose } \\
\hline $\begin{array}{l}13134 \\
13178 \\
13756\end{array}$ & $\begin{array}{l}1.80 \\
1.80 \\
2.00\end{array}$ & $\begin{array}{l}2.04 \\
2.07 \\
2.38\end{array}$ & $\begin{array}{l}25.2 \\
25.2 \\
30.0\end{array}$ & $\begin{array}{l}26.3 \\
26.1 \\
30.7\end{array}$ & $\begin{array}{l}7.06 \\
7.12 \\
7.01\end{array}$ & $\begin{array}{l}0.36 \\
0.40 \\
0.32\end{array}$ & $\begin{array}{l}7.41 \\
7.40 \\
7.56\end{array}$ & $\begin{array}{l}0.87 \\
0.85 \\
1.31\end{array}$ \\
\hline
\end{tabular}

* Ileal sacs incubated at $37^{\circ} \mathrm{C}$ for 60 minutes under $95 \% \mathrm{O}_{2}-5 \% \mathrm{CO}_{2}$.

$\dagger$ No significant change in $\mathrm{NH}_{3}-\mathrm{N}$ occurred on the mucosal side after incubation. Initial mucosal volume $=50 \mathrm{ml}$.

As listed in Table III, values calculated with Equation 2 for the final mucosal and serosal ammonia tensions in aerobic experiments reveal a pressure gradient averaging $29.7 \%$ in ileal sacs and no significant gradient in jejunal sacs.

To study further the relation between ammonia movement and hydrogen ion concentration, we established transmucosal $\mathrm{pH}$ gradients in ileal sacs by adding $1 \mathrm{~N}$ hydrochloric acid or $1 \mathrm{~N}$ sodium hydroxide to either serosal or mucosal solutions. Regardless of whether the final $\mathrm{pH}$ gradient tended to favor (mucosal $\mathrm{pH}>\operatorname{serosal} \mathrm{pH}$ ) or to retard (serosal $\mathrm{pH}>$ mucosal $\mathrm{pH}$ ) ammonia transport from the mucosal to the serosal surface, such mucosal-to-serosal movement always occurred and was of the same magnitude as in prior experiments recorded in Table III. Thus, contrary to expectation, acidification of serosal contents did not augment ammonia transport, and acidification of the mucosal compartment did not abolish ammonia transport. Individual experiments are summarized in Table IV.

Finally, ileal sacs were incubated in solutions containing phosphate (KRP) rather than bicarbonate buffer and gassed with $100 \% \mathrm{O}_{2}$. As illustrated in Table IV, when bicarbonate was absent from the mucosal and serosal compartments, no ammonia transport occurred notwithstanding the development of favorable $\mathrm{pH}$ and partial pressure gradients. When glucose was added to the KRP, the sugar was transported actively (not shown) despite continued absence of transport of ammonia. Positive ammonia transport was re-established upon adding bicarbonate to the KRP (not shown). Some of these results have been reported previously $(19,20)$.

\section{Discussion}

In the intact animal, ammonia is absorbed in the small and large intestines. Although postprandial ammonia levels are 4 to 13 times higher in the venous effluent from the colon than in the blood from the small bowel (6), the importance of the small intestine as a site for ammonia absorption is evidenced by a rise in the ammonia content of portal blood 30 minutes after the ingestion of protein $(10,21)$ and by the disappearance of ammonia from a jejunal perfusate (22). A more precise characterization of the factors influencing ammonia transport is hindered by the nature of the in vivo preparation, the major obstacle being an inability to control and to measure the environment of the serosal side of the gut membrane. In 
vitro methods overcome this limitation and provide a model for quantitative experimentation.

Under the conditions of these experiments, the absorption of ammonia by the small intestine occurs predominantly in the ileum. An analysis of the factors potentially responsible for the preferential transport of ammonia by the ileum must be concerned first with the passage of weak acids and bases across semipermeable membranes, i.e., nonionic diffusion $(23,24)$. Ammonia exists in solution as ammonium ion and as ammonia gas, a relationship described by the following equations (25) :

$$
\begin{gathered}
\mathrm{NH}_{4}{ }^{+} \rightleftharpoons \mathrm{NH}_{3}+\mathrm{H}^{+} ; \\
\left(\left[\mathrm{NH}_{3}\right]\left[\mathrm{H}^{+}\right]\right) / \mathrm{NH}_{4}{ }^{+}=\mathrm{K}^{\prime} \mathrm{a} ; \\
\mathrm{pH}=\mathrm{pK}+\log \left(\mathrm{NH}_{3} / \mathrm{NH}_{4}{ }^{+}\right) .
\end{gathered}
$$

Since most cells are relatively impermeable to $\mathrm{NH}_{4}{ }^{+}$and freely permeable to $\mathrm{NH}_{3}(26-29)$, the distribution of ammonia across a membrane is dependent upon the tension of $\mathrm{NH}_{3}$ on each side of the membrane, diffusion occurring from the area of greater partial pressure to that of lesser pressure. The tension of free ammonia, however, is a function of hydrogen ion concentration (Equation 5) $(26,29)$; therefore, if two fluid compartments contain equal quantities of total ammonia and a $\mathrm{pH}$ gradient is established, there will be diffusion from the side of lower hydrogen ion concentration (higher $\mathrm{pH} \rightarrow$ higher $\mathrm{NH}_{3}$ ) to the side of higher hydrogen ion concentration (lower $\mathrm{pH}$ $\rightarrow$ lesser $\mathrm{NH}_{3}$ ).

In examining the data recorded in Table III, one might make a case for such a $\mathrm{pH}$-dependent partition of ammonia across the wall of the small intestine. Initially, identical solutions are present on both sides of the mucosa. During aerobic incubation, the ileum secretes bicarbonate from the serosal to the mucosal surface, and this is accompanied by acidification of the serosal contents. Similar findings were reported by Wilson and Kazyak (30). The $\mathrm{pH}$ gradient that is created causes a shift in ammonia equilibrium toward increased $\mathrm{NH}_{4}{ }^{+}$and decreased $\mathrm{NH}_{3}$ in the serosal compartment, and the resulting partial pressure differential apparently favors transport of ammonia from the mucosal into the serosal compartment. In the ileum incubated anaerobically and in the jejunum, however, there is minimal to absent bicarbonate secretion, no significant transmucosal $\mathrm{pH}$ gradient, no difference in ammonia tension between the mucosal and serosal solutions, and, therefore, no transport of ammonia. The above hypothesis breaks down, however, when net ammonia movement and acidification of the serosal compartment are dissociated from one another. If ammonia crosses the ileum by nonionic diffusion, then the creation of an adverse hydrogen ion gradient (relative alkalinization of serosal contents) should effectively abolish movement of that ion from the mucosal to the serosal surface, and the production of a favorable $\mathrm{pH}$ gradient (relative acidification of serosal contents) should enhance positive ammonia transport. That these relationships do not obtain is evidenced by the experiments illustrated in Table IV in which ammonia transference is not influenced by the alteration of transmucosal $\mathrm{pH}$ gradients. In a similar manner, the laws of nonionic diffusion are violated when bicarbonate is absent from the test solution, i.e., ammonia is not transported despite a favorable hydrogen ion gradient and despite conditions that permit normal transport of glucose and other charged particles. It is apparent, therefore, that in order to reconcile ammonia movement with the observed experimental data, one must look to other transport mechanisms.

To label transport of a charged particle as "active" $(31,32)$, one must demonstrate 1$)$ that movement of the ion occurs against a chemical and an electrical gradient, and 2) that solvent drag is not responsible for the observed transport. Other features that suggest but do not define active transport are 3) depression of transport with inhibition of energy-yielding reactions, and 4) saturation phenomena.

Transference of ammonia from the mucosal to the serosal surface against a chemical concentration gradient is observed in the ileum but not in the jejunum. The influence of water movement on this passage of ammonia can be assessed by calculating the apparent concentration of ammonia in the solution moving across the membrane. If water movement is primary (solvent drag), the concentration of ammonia in the solution transported should be no higher than in the compartment of origin, and there should be no ammonia transport in the absence of water movement. As recorded in Table II, the ammonia concentration 
of the fluid crossing the jejunal wall is similar to that of the initial test solution, whereas the solution transported in the ileum contains a threefold increment in ammonia concentration. Likewise, in contrast to that in the jejunum, transport of ammonia in the ileum occurs in the absence of fluid movement (Table III). Thus, although solvent drag can be invoked as the mechanism for jejunal transference of ammonia, it cannot be responsible for ammonia transport in the ileum.

The inhibition or abolition of ammonia transport by anaerobiosis and by the metabolic inhibitors, sodium cyanide and 2,4-dinitrophenol (Figure 3 ), demonstrates that energy is required to move ammonia across the ileal wall. That a surface-catalyzed or carrier-mediated mechanism may be operative is suggested by characteristic firstorder Michaelis-Menten kinetics (33) (Figure 2 ), although caution must be exercised in interpreting these data since, strictly speaking, initial rates rather than intermediate rates should be employed. The concept of a surface membrane transport site for ammonium ion is not new, however, and is supported by Bihler and Crane (34), who noted $\mathrm{NH}_{4}{ }^{+}$inhibition of active glucose absorption, presumably as a result of competition by $\mathrm{NH}_{4}{ }^{+}$for a $\mathrm{Na}^{+}$-dependent carrier system located in the brush border of the intestinal epithelial cell.

From the foregoing discussion it is evident that, save for the documentation of movement against an electrical gradient, the criteria for active transport of ammonia have been satisfied. Unfortunately, we did not determine transmembrane potential differences, and a firm conclusion regarding active transport must await such measurements. It is tempting to speculate, though, that passage of ammonium ion from the mucosal to the serosal surface does take place in the presence of an adverse electrical gradient since, during sodium transport, the serosa is positively charged relative to the mucosa $(31,35)$.

Finally, it should be noted that in studies employing ammonia-free test solutions, no significant evolution of metabolic (intrinsic) ammonia was detected in the mucosal or the serosal solution in conjunction with the transport of glucose and electrolytes. This is in contrast to the finding by Ingraham and Visscher (36) of intraluminal ammonia accumulation accompanying active osmotic work in vivo. To reconcile these divergent observations, one must consider the dissimilar nature of the experimental procedures employed. In the intact animal the bloodstream is a potent ammonia source. When Thiry-Vella loops are perfused with ammonia-free solutions, a gradient is established that favors movement of ammonia into the intestinal contents. The in vitro preparation contains no ammonia on either side of the mucosa, and the appearance of metabolic ammonia can derive only from the intracellular space of the intestinal sac. It is apparent, therefore, that the data from these two sets of experiments are neither comparable nor incompatible.

\section{Acknowledgments}

We wish to thank Mrs. Confesora Rodriquez and Mrs. Fannie Herschman for technical assistance. The Figures are the work of Miss Ann Solomon. We are indebted to Dr. Jacob Grossman for advice and criticism.

\section{References}

1. Van Slyke, D. D., R. A. Phillips, P. B. Hamilton, R. M. Archibald, P. H. Futcher, and A. Hiller. Glutamine as source material of urinary ammonia. J. biol. Chem. 1943, 150, 481.

2. Sartorius, O. W., J. C. Roemmelt, and R. F. Pitts. The renal regulation of acid-base balance in man. IV. The nature of the renal compensations in ammonium chloride acidosis. J. clin. Invest. 1949, 28, 423.

3. Bessman, S. P., and A. N. Bessman. The cerebral and peripheral uptake of ammonia in liver disease with an hypothesis for the mechanism of hepatic coma. J. clin. Invest. 1955, 34, 622.

4. Summerskill, W. H. J., S. J. Wolfe, and C. S. Davidson. The metabolism of ammonia and $\alpha$-keto-acids in liver disease and hepatic coma. J. clin. Invest. $1957,36,361$.

5. Folin, O., and W. Denis. Protein metabolism from the standpoint of blood and tissue analysis: the origin and significance of the ammonia in the portal blood. J. biol. Chem. 1912, 11, 161.

6. Silen, W., H. A. Harper, D. L. Mawdsley, and W. L. Weirich. Effect of antibacterial agents on ammonia production within the intestine. Proc. Soc. exp. Biol. (N. Y.) 1955, 88, 138.

7. Chalmers, T. C. Pathogenesis and treatment of hepatic failure. New Engl. J. Med. 1960, 263, 23, 77.

8. Gaustad, V. Transient hepatargy. Acta med. scand. 1949, $135,354$.

9. Phillips, G. B., R. Schwartz, G. J. Gabuzda, Jr., and C. S. Davidson. The syndrome of impending hepatic coma in patients with cirrhosis of the liver given certain nitrogenous substances. New Engl. J. Med. 1952, 247, 239. 
10. White, L. P., E. A. Phear, W. H. J. Summerskill, and S. Sherlock. Ammonium tolerance in liver disease: observations based on catheterization of the hepatic veins. J. clin. Invest. 1955, 34, 158.

11. Summerskill, W. H. J., S. J. Wolfe, and C. S. Davidson. The management of hepatic coma in relation to protein withdrawal and certain specific measures. Amer. J. Med. 1957, 23, 59.

12. Sherlock, S., W. H. J. Summerskill, and A. M. Dawson. The treatment and prognosis of hepatic coma. Lancet 1956, 2, 689.

13. Wilson, T. H., and G. Wiseman. The use of sacs of everted small intestine for the study of the transference of substances from the mucosal to the serosal surface. J. Physiol. (Lond.) 1954, 123, 116.

14. Umbreit, W. W., R. H. Burris, and J. F. Stauffer. Manometric Techniques. Minneapolis, Burgess, 1964, pp. 132-133.

15. Seligson, D., and K. Hirahara. The measurement of ammonia in whole blood, erythrocytes, and plasma. J. Lab. clin. Med. 1957, 49, 962.

16. Nelson, N. A photometric adaption of the Somogyi method for the determination of glucose. J. biol. Chem. 1944, 153, 375.

17. Lineweaver, H., and D. Burk. The determination of enzyme dissociation constants. J. Amer. chem. Soc. 1934, 56, 658.

18. Manning, R. T. Chemistry of ammonia intoxication. Biochem. Clin. 1964, 3, 225.

19. Mossberg, S. M., G. Ross, and B. Weingarten. Ammonium transport in the small intestine of the golden hamster (abstract). Clin. Res. 1965, 13, 258.

20. Mossberg, S. M., G. Ross, and B. Weingarten. Ammonium transport by the small intestine of the golden hamster. Nature (Lond.) 1966, 212, 1588.

21. Webster, L. T., Jr., C. S. Davidson, and G. J. Gabuzda. Effect on portal blood ammonium of administering nitrogenous substances to patients with chronic hepatic disease. J. Lab. clin. Med. 1958, 52, 501.

22. Ewe, K., and W. H. J. Summerskill. Transfer of ammonia in the human jejunum. J. Lab. clin. Med. 1965, 65, 839.
23. Shore, P. A., B. B. Brodie, and C. A. M. Hogben. The gastric secretion of drugs : a $\mathrm{pH}$ partition hypothesis. J. Pharmacol. exp. Ther. 1957, 119, 361.

24. Milne, M. I., B. H. Scribner, and M. A. Crawford. Non-ionic diffusion and the excretion of weak acids and bases. Amer. J. Med. 1958, 24, 709.

25. Bromberg, P. A., E. D. Robin, and C. E. Forkner, Jr. The existence of ammonia in blood in vivo with observations on the significance of the $\mathrm{NH}_{4}{ }^{+}$ $\mathrm{NH}_{3}$ system. J. clin. Invest. 1960, 39, 332.

26. Jacobs, M. H., and D. R. Stewart. The distribution of penetrating ammonium salts between cells and their surroundings. J. cell. comp. Physiol. 1936, 7, 351.

27. Jacobs, M. H. Some aspects of cell permeability to weak electrolytes. Cold Spr. Harb. Symp. quant. Biol. 1940, 8, 30.

28. Warren, K. S., and D. G. Nathan. The passage of ammonia across the blood-brain-barrier and its relation to blood $\mathrm{pH}$. J. clin. Invest. 1958, 37, 1724.

29. Lawrence, W., Jr., J. A. Jacquez, S. G. Dienst, J. W. Poppell, H. T. Randall, and K. E. Roberts. The effect of changes in blood $\mathrm{pH}$ on the plasma total ammonia level. Surgery 1957, 42, 50.

30. Wilson, T. H., and L. Kazyak. Acid-base changes across the wall of hamster and rat intestine. Biochim. biophys. Acta (Amst.) 1957, 24, 124.

31. Curran, P. F., and A. K. Solomon. Ion and water fluxes in the ileum of rats. J. gen. Physiol. 1957, $41,143$.

32. Cooperstein, I. L., and C. A. M. Hogben. Ionic transfer across the isolated frog large intestine. J. gen. Physiol. 1958, 42, 461.

33. Michaelis, L., and M. L. Menten. Die Kinetik der Invertinwirkung. Biochem. Z. 1913, 49, 333.

34. Bihler, I., and R. K. Crane. Studies on the mechanism of intestinal absorption of sugars. $\mathrm{V}$. The influence of several cations and anions on the active transport of sugars, in vitro, by various preparations of hamster small intestine. Biochim. biophys. Acta (Amst.) 1962, 59, 78.

35. Curran, P. F. Na, Cl, and water transport by rat ileum, in vitro. J. gen. Physiol. 1960, 43, 1137.

36. Ingraham, R. C., and M. B. Visscher. Further studies on intestinal absorption with the performance of osmotic work. Amer. J. Physiol. 1938, 121, 771. 